\begin{tabular}{l|c|c|c|c}
\hline \multicolumn{1}{c|}{$\begin{array}{c}\text { Apgar score } \\
10 \mathrm{~min} .\end{array}$} & \multicolumn{3}{|c}{ F.D.P. positive/negative } \\
\hline 1 min. & $0-3$ & $4-6$ & $7-10$ & Total \\
\hline $0-3$ & $8 / 0$ & $9 / 2$ & $1 / 2$ & $18 / 4$ \\
\hline $4-6$ & $0 / 0$ & $1 / 4$ & $6 / 17$ & $7 / 21$ \\
\hline $7-10$ & $0 / 1$ & $1 / 3$ & $10 / 25$ & $11 / 29$ \\
\hline Total & $8 / 1$ & $11 / 9$ & $17 / 44$ & $36 / 54$ \\
\hline
\end{tabular}

We agree with Dr. Chadd and colleagues when they say that there is a positive correlation between a low Apgar score and raised levels of F.D.P. However, Dr. Apgar has pointed out ${ }^{3}$ that the score at 1 minute does not reflect oxygenation itself. Furthermore, "biochemical confirmation of hypoxia" obtained by capillary blood gas determinations is inappropriate and must be performed on arterial blood, as has been clearly shown by, among others, Koch and Wendel..$^{5}$

In our opinion, therefore, a one-minute

\title{
Doctors and Overpopulation
}

SIR,-The generous correspondence (22 January, p. 242) following our letter (8 January, p. 108) has raised many points of great interest. Perhaps I could comment on one of these by Dr. Thomas Lodge. I think it is a most important one-namely, that what we are "suggesting is nothing less than the use of organized medicine as an instrument of Government political policy at the expense of individual freedom." Were such a suggestion indeed made I am sure all of us would settle for our duty to our individual patients. But of course we have suggested no such thing.

In practice what is happening today is that up and down the country women in trouble are going to their doctors asking for help in the termination of pregnancies that they do not wish to have. Depending on which part of the country they live in, they will either get the termination under the Health Service or not. What some of us are saying is that these patients should be treated with comparable understanding, whatever their home town. What we are also saying is that family planning should be energetically pursued. That responsible and senior doctors in hospital and practice should concern themselves and see that patients get the contraceptive advice that they want. Among the other things we are saying is that a sensible working man who wants to plan his family and decides to have a vasectomy should not be asked to pay up to $£ 40$, but should have it done under the National Health Service. I fail to see how any of these measures are in any way at the "expense of individual freedom." Duty to our patients and planning to protect our children from the horrors of overpopulation happily go hand in hand.

Some of your readers may remember that at the end of our letter we asked for support from doctors and medical students. It might be of interest that we have received over 500 letters of support and two criticizing our efforts.-I am, etc.,

London N.10

GEORGE MORRIS

SIR,-We are partners in general practice in Birmingham, and it is distressingly clear to us that even in this day and age a high score and capillary oxygen tension assays do not warrant Dr. Chadd's suggestion of a causal relationship between hypoxia and raised levels of F.D.P. It appears that all we can say today is that a low Apgar score reflects the existence of some underlying pathologic state not necessarily requiring the presence of hypoxia.-We are, etc.,

H. EKELUND

Department of Paediatrics and the Coagulation Laboratory,

Malmó

O. FinNSTRŐM

Department of Paediatrics,

University Hospita

1 Ekelund, H., and Finnström, O., Acta Paediatric Scandinavica, 1970, 59, Suppl., 206, p. 31. Hedner, U., and Nilsson, I. M., Acta Medica Scandinavica, 1971, 189, 471.
19th America, Apgar, V., Pediatric

1966, 13, 645. Kerr, M. M., Douglas, T. A.,

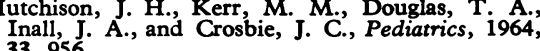
Koch, G., and Wendel, H., Acta Paediatrica Scandinavica, 1967, 56, 10.

proportion of conceptions remain unplanned and unwanted. While we have no hesitation in giving family planning advice and assistance to any of our patients who seem "at risk," even so, in our own practice, we still have to deal with a number of unwanted pregnancies. Apart from our N.H.S. practice (which includes affiliation to the local general practitioner unit so that we deal with all aspects of pregnancy in our patients), we also work in a private nursing home where during the last two years we have collected extensive experience in performing abortions and male and female sterilization.

At the present time we are going through the case records of the very large number of pregnancies terminated by us. These show that, in experienced hands, the complications following vaginal abortion during the first and second trimester of pregnancy (normally up to 22 weeks from the date of the las menstrual period) by various methods are even fewer than those reported recently in articles published on the subject by N.H.S gynaecologists. This morbidity rate is particularly low for cases up to 14 weeks.

With regard to female sterilization, we now perform this operation through a very small incision using a McEvedy proctoscope to deliver the Fallopian tubes; in our opinion this technique is superior to the laparoscopic method and requires usually only a shor stay for the patient.

As a result of our work, we have come into contact with a large number of general practitioner colleagues up and down the country and are often saddened by the attitude of many of them not only towards family planning and abortion but also sterilization. We respect the moral and religious views of those who consider that the prescribing of oral contraception to single women is unthinkable, or who feel that abortion, except on the most stringent medical grounds, is evil. However, we deplore attempts made by some of them to impose their own moral scruples on their patients and their efforts to withhold referral to doctors of a different persuasion.

We ourselves find no difficulty on the one hand in providing antenatal care for those of our patients who wish to continue with their pregnancies, while on the other hand offering assistance in the fields of contraception, abortion, and sterilization to others who seek this from us and for whom we consider such help desirable.

We congratulate the signatories to the letter (8 January, p. 108) in their attempt to form a body of medical opinion in Britain which takes cognisance of the population problem as a whole. For our part, we are happy to extend our co-operation in this project in any way which may be helpful to their cause. We would welcome a visit from any colleague who would like to discuss with us the various aspects of population control, and would be happy to demonstrate our technique for termination of pregnancies and male and female sterilization. -We are, etc.

Peter Gittins

Birmingham

F. K. Minwalla

SIR,-With regard to the letter "Doctors and Overpopulation" (8 January, p. 108), we cannot accept the suggestion that one way of restricting the population should be by increasing the number of abortions performed. Family planning and in some cases sterilization are reasonable methods of control, but abortion is in our opinion and still in that of many others in quite a different category.

For the Abortion Act to operate evenly over all the country either all doctors would have to feel the same way about it, as we do not and never will, or many would have to subordinate their judgement and ethical views to a majority viewpoint-and would this not be the end of personal and professional freedom? We would think that education and suggestion, financial help with family planning if needed, and practical help or transport for mother and children to get to their doctors or clinics are the main requirements.-We are, etc.,

A. JACQUELIN HILL F. R. GAMMAN

Dursley, Glos

${ }^{*}$ * Appendix II of the B.M.A. Council's Annual Report, "Inquiry into the Working of the Abortion Act," appears at p. 33 of the Supplement. ED., B.M.F.

\section{Central Nervous Disturbance with Pentazocine}

SIR,-Recently I had as a patient a 45-yearold well-educated woman who was admitted to hospital in severe pain due to cervical spondylosis. She had no history of personality disorders. On admission she was treated with analgesics, muscle relaxants, cervical traction, and a cervical collar. Initially she required pethidine, but this was changed to pentazocine after a few days. As the response was slow, she had pentazocine over a period of two and one-half weeks.

One evening I was called to see the patient urgently because she was hallucinated, very anxious, and apprehensive. She complained of tingling all over her body. Her pulse rate was extremely rapid, and the blood pressure raised. She told me that on closing her eyes she was seeing a complex pattern of psychedelic colours. She had had her last iniection of pentazocine an hour previously. Then and only then did she tell me that for the previous few days she had felt strange soon after receiving the pentazocine injections, but she did not think it was worth mentioning this to the nursing staff. Later she described her incident very clearly and 
told me that she had had a sensation of impending death.

I treated this particular episode with an intramuscular injection of chlorpromazine and she was perfectly normal and rational the next morning. Needless to say, she was not given any more pentazocine.

It is worth noting this particular side effect which was pointed out in your account of this drug (16 May, 1970, p. 409). It is extremely rare and pentazocine is an otherwise excellent analgesic, which we have used fairly extensively in this hospital and with good results. It provides an effective analgesic stronger than codeine but less likely to cause addiction and respiratory depression than morphia.-I am, etc., Shanta Bhawan Hospital,
Katmandu, Nepal

W. M. GouLD

\section{Spontaneous Fractures of Pelvis in Rheumatoid Arthritis}

SIR,-Dr. R. T. Taylor and others (11 December, p. 663) stressed the importance of recognition of spontaneous fractures of pelvis in rheumatoid arthritis. We feel, however, that not only the recognition of these fractures should be stressed, but also the search for the aetiology. The following case history illustrates this point.

A 62-year-old woman with a history of classical rheumatoid arthritis for 22 years was recently admitted for treatment of exacerbation of her disease. Owing to muscle weakness and arthritis of the feet she had been bedridden for several weeks. $X$-ray of the pelvis showed a fracture line in the left iliac bone and right pubic rami. $X$-ray of the ribs revealed fractures with callus on the right tenth and eleventh rib. These fractures were not present on $x$-rays taken one year previously. Details of the biochemical evaluation are given in the Table.

\begin{tabular}{|c|c|}
\hline Serum & $\begin{array}{l}\text { Calcium }(\mathrm{mg} / 100 \mathrm{ml}) 7.6 \\
\text { Phosphorus (mg/100 ml) } 3.9 \\
\text { Alkaline Phosphatase } 2 \text { B.U. }\end{array}$ \\
\hline Urine & $\begin{array}{l}\text { Calcium (mg } / 24 \mathrm{hrs} .) 12.8 \\
\text { Total Hydroxyproline (mg/24 hrs.) } 40 \\
\text { Four-hour Calcium Retention Test } 85 \%\end{array}$ \\
\hline
\end{tabular}

A low serum calcium, calcium-phosphorus product, and urinary calcium excretion, and a high four-hour calcium retention test ${ }^{1}$ were found. Radiological exploration of the gastrointestinal tract revealed no abnormality. Dxylose test, serum cholesterol, and serum carotene were normal. Her home diet was found sufficient for calcium intake, $1.176 \mathrm{mg} /$ day, but deficient for vitamin D, 70 I.U./day.

The histology of an undecalcified bone sample of the iliac crest after double tetracycline labeling revealed: a relative osteoid volume of $10.5 \%$ (normally less than $4 \%$ ) a relative osteoid surface area of $66 \%$ (normally less than $17.5 \%$ ); an osteoid seam thickness of $8.8 \mu$ (normally less than $8.6 \mu$ ), and a lack of a calcification front in some areas. On the basis of radiological, biochemical, and histological evidences the diagnosis of nutritional osteomalacia was made. The nutritional osteomalacia probably was accentuated by a lack of sun irradiation as the patient was house bound, and by a metabolic disturbance due to anticonvulsant drugs given for epilepsy for the past 25 years. 2

Parenteral vitamin $D_{2}$ treatment, $15 \mathrm{mg}$, normalized the biochemical values and raised the serum alkaline phosphatase activity and urinary calcium excretion. Muscle weakness was soon relieved and the patient left the hospital ambulant.

Since four cases out of six $(66 \%)$ in Dr. Taylor and colleagues' series had a low serum calcium, we wonder if these patients were not suffering from osteomalacia rather than from osteoporosis as the authors suggest. In the description by Devas ${ }^{3}$ of 25 cases of stress fractures of the femoral neck no biochemical or histological data are given, which makes us suspect that in that series also many patients might have been suffering from osteomalacia.

Since osteomalacia is a curable disease, all diagnostic techniques have to be used to exclude this aetiology when spontaneous fractures are observed.

We thank Professor F. Meersseman for histological examination.

-We are, etc.,

J. DEQUEKER H. HEYLEN

Rheumatology Unit. A. Burssens

Academic Hospital Pellenberg (Leuven), elgium

1 Nordin, B. E. C., and Fraser, R., Lancet, 1956, 2 Dent, C. E., Richens, A., Rowe, D. J. F., and Stamp, T.'C. B., British Medical łournal, 1970 4,69

3 Devas, M. B., Fournal of Bone and foint Surgery,
$1965,47 \mathrm{~B}, 728$.

General Practitioner Maternity Units

SIR,-Dr. J. Oliver Woods (25 December 1971, p. 803) refers to Hobbs and Acheson's finding ${ }^{1}$ that the perinatal mortality in the Oxford area in 1962 was significantly higher in practices with access to the general practitioner maternity units than in practices without access. They concluded that general practitioner maternity units were being used

Chipping Norton Hospital: Perinatal Mortality by Place of Booking and Place of Delivery, 1962-70

\begin{tabular}{|c|c|c|c|c|c|c|c|c|c|c|c|c|}
\hline \multirow{2}{*}{ Year } & \multicolumn{3}{|c|}{$\begin{array}{c}\text { Booked and Delivered in } \\
\text { Chipping Norton } \\
\text { Hospital }\end{array}$} & \multicolumn{3}{|c|}{$\begin{array}{c}\text { Emergency Deliveries in } \\
\text { Chipping Norton } \\
\text { Hospital }\end{array}$} & \multicolumn{3}{|c|}{$\begin{array}{l}\text { Booked for Chipping } \\
\text { Norton Hospital but De- } \\
\text { livered in Consultant Unit }\end{array}$} & \multicolumn{3}{|c|}{$\begin{array}{l}\text { All Patients Booked for } \\
\text { Chipping Norton } \\
\text { Hospital }\end{array}$} \\
\hline & $\underset{\text { Births }}{\text { All }}$ & $\begin{array}{l}\text { Peri- } \\
\text { natal } \\
\text { Deaths }\end{array}$ & $\begin{array}{c}\text { Perinatal } \\
\text { Mortality } \\
\text { Rate/ } \\
1,000\end{array}$ & Births & $\begin{array}{c}\text { Peri- } \\
\text { natal } \\
\text { Deaths }\end{array}$ & $\begin{array}{c}\text { Perinatal } \\
\text { Mortality } \\
\text { Rate/ } \\
1,000\end{array}$ & $\underset{\text { Births }}{\text { All }}$ & $\begin{array}{c}\text { Peri- } \\
\text { natal } \\
\text { Deaths }\end{array}$ & $\begin{array}{c}\text { Perinatal } \\
\text { Mortality } \\
\text { Rate/ } \\
1,000\end{array}$ & $\underset{\text { Births }}{\text { All }}$ & $\begin{array}{c}\text { Peri- } \\
\text { natal } \\
\text { Deaths }\end{array}$ & $\begin{array}{c}\text { Perinatal } \\
\text { Mortality } \\
\text { Rate/ } \\
1,000\end{array}$ \\
\hline 1962 & 259 & 7 & 27 & 9 & 0 & 0 & 7 & 1 & 143 & 266 & 8 & 30 \\
\hline 1963 & 259 & 3 & 12 & 8 & 1 & 125 & 16 & 1 & 63 & 275 & 4 & 15 \\
\hline 1964 & 248 & 2 & 8 & 12 & 0 & 0 & 18 & 1 & 56 & 266 & 3 & 11 \\
\hline 1965 & 264 & 1 & 4 & 12 & 1 & 83 & 27 & 4 & 148 & 291 & 5 & 17 \\
\hline 1966 & 282 & 2 & 7 & 13 & 0 & 0 & 17 & 1 & 59 & 299 & 3 & 10 \\
\hline 1967 & 256 & 1 & 4 & 10 & 0 & 0 & 59 & 4 & 68 & 315 & 5 & 16 \\
\hline 1968 & 265 & 2 & 8 & 11 & 0 & 0 & 59 & 4 & 68 & 324 & 6 & 19 \\
\hline 1969 & 260 & 0 & 0 & 8 & 0 & 0 & 51 & 5 & 98 & 311 & 5 & 16 \\
\hline 1970 & 285 & 0 & 0 & 10 & 0 & 0 & 49 & 2 & 41 & 334 & 2 & 6 \\
\hline
\end{tabular}

\section{Motorway Disasters}

SIR,-Dr. J. F. Hindle and his colleagues (1 January, p. 47) refer to the anxiety of the staff of the accident service at the Luton nd Dunstable Hospital who go out to deal with multiple crashes on the M1 that they had no insurance cover from their employers in the event of their own injury. They and others whose employment in the Health Service carries special risks asternative to consultant care and not They thought it would be interesting to know whether increasing experience in the selection of cases for delivery in general the situation.

general practitioner maternity unit unit at Oxford and 13 miles from the consultant unit at Banbury. As a result of a survey carried out by the doctors in Chipping Norton in 1963 and of the findings of whether the perinat it was decided to see proved. An Oxford obstetrician agreed to with the general practitioner obfor booking in the unit and, secondly, to monitor cases which had begun to present difficulties. A close and enthusiastic relationship was quickly established between the obstetrician and the general practitioners. The Cranbrook Committee criteria were used as a basis for the selection of cases but, the years have gone by, the rules have sequences.

The Table has been provided by the Oxford Record Linkage Study Group, which has continued to monitor the hospitals in the Oxford Regional Hospital Board area he perinatal mortality rate six in 1970. It will also show a steady reduction in deaths in cases booked for Chipping Norton Hospital but delivered in the consultant unit. I think these figures show what can be done by close co-operation between an obstetrician, general practitioner obstetricians, and midwives, even in a general practioner maternity hospital distant from a consultant unit.-I am, etc.,

H. M. STEEL

should know that the British Medical Association with the support of the defence organizations has obtained valuable assurances from the Department of Health. They should also know that the Superannuation Bill 1971 now before Parliament empowers the Secretary of State to pay injury allowances to any person engaged in the Health Service, not, as heretofore, solely to those in is some 21 miles from the Nuffield maternity 